\title{
Territorial behavior among Western North American foragers: Allee effects, within group cooperation, and between group conflict
}

\author{
Brian F. Codding ${ }^{a,}{ }^{*}$, Ashley K. Parker ${ }^{a}$, Terry L. Jones ${ }^{b}$ \\ a Department of Anthropology, University of Utah, 270 S. 1400 E., Salt Lake City, UT 84112, USA \\ b Department of Social Sciences, California Polytechnic State University, San Luis Obispo, CA 93407, USA
}

\section{A R T I C L E I N F O}

Keywords:

Behavioral ecology

Territoriality

Allee's principle

Ideal free distribution model

Hunter-gatherers

North America

\begin{abstract}
A B S T R A C T
Ethnographic populations throughout Western North America relied on strategies and institutions to protect resources for exclusive use, though the degree of territorial defense varied significantly across the region. Attempts to explain this variation typically focus on the ecological contexts that promote economic defensibility, however, it is increasingly recognized that social dynamics also play a critical role because territoriality requires within group coordination or cooperation. Building on ideal distribution models, here we present a hypothesis for territorial defense that links ecological, economic, and social factors through Allee's principle: positive covariance between utility and the number of cohabiting individuals up to intermediate population densities. We predict that when foragers experience an Alleelike economy of scale, individual interests are more likely to align and facilitate within group cooperation and the exclusion of out-group competitors. We evaluate this model using data on 157 foraging populations from contact-era Western North America. The results support our predictions, showing that larger cooperative groups have greater levels of territorial behavior, specifically higher levels of resource ownership and intergroup violence. Thus, incorporating Allee's principles may help to explain how territorial behaviors can emerge, driven by the individual benefits gained from aggregation in ecological contexts where economic returns to scale make in-group cooperation and out-group exclusion worthwhile.
\end{abstract}

\section{Introduction}

Territorial defense is costly. It may require individuals to establish and maintain institutions governing resource ownership and property rights, and possibly to uphold those claimed resources or land with physical force. But territorial defense has obvious benefits too, including exclusive resource use and increased food security.

Evaluating these trade-offs, ecologically minded anthropologists suggest that individuals should only engage in territorial behavior when the benefits outweigh the costs, which should occur when critical resources are both dense and predictable (DysonHudson and Smith, 1978). However, even if these ecological conditions are met, individuals may still not find territorial defense worthwhile (Cashdan, 1983; Smith, 1988). One possible reason for this centers on costs of social dilemmas (Freeman and Anderies,

\footnotetext{
* Corresponding author.

E-mail address: brian.codding@anthro.utah.edu (B.F. Codding).
}

2015). Importantly, any one individual should not find territorial investment worthwhile until the proportion of cooperating defenders provide benefits that outweigh the cost incurred by freeriders who refuse to recognize ownership or engage in defense (Willems et al., 2015). With this in mind, we suggest that territorial defense should only emerge when the interests of multiple individuals are aligned, which itself may be favored under particular ecological, economic, and social circumstances.

To identify the conditions that may promote territorial behavior, here we build on an ideal distribution model (IDM, Fretwell and Lucas, 1969) from population ecology. IDMs are particularly useful for explaining cooperative behavior like territoriality because they are designed to examine the aggregate effects of individual behavior (Sutherland, 1996). Anthropological applications of IDMs have advanced our understanding of colonization events (e.g., Allen and O'Connell, 2008; O'Connell and Allen, 2012; Giovas and Fitzpatrick, 2014; Yaworsky and Codding, 2018), settlement patterns (e.g., Codding et al., 2012; Jazwa et al., 2013; Codding and Jones, 2016), pastoral management (e.g., Moritz et al., 2013, 2014, 2015), agricultural investment (e.g., McClure et al., 2006), 
marriage patterns (e.g., Borgerhoff Mulder, 1990), children's foraging (Disma et al., 2011), linguistic mosaics (Codding and Jones, 2013), and despotic behaviors (e.g., Kennett et al., 2009; Winterhalder et al., 2010; Bell and Winterhalder, 2014; Prufer et al., 2017), including territoriality (Jazwa et al., 2017, this issue).

The basic model proposes that the utility of an activity (the benefits minus the costs) will vary depending on the number of conspecifics also engaged in that activity. Used mostly to examine subsistence, the model specifies a functional relationship between per capita utility (e.g., fitness, energetic returns) and the size of the cohabiting population (e.g., others in the same patch or habitat). This relationship is often thought to take the form of negative density dependence (NDD), where each additional person lowers everyone's utility (Fig. $1 \mathrm{a} \rightarrow \mathrm{b}$ ). Alternatively, it may take on an "Allee-like" form (see Allee, 1931, see also Courchamp et al., 1999; Stephens and Sutherland, 1999; Stephens et al., 1999), where each additional person initially has a net positive effect on everyone's utility (Fig. $1 \mathrm{c} \rightarrow \mathrm{d}$ ), until some saturation point (Fig. $1 \mathrm{~d}$ ) when the relationship returns to negative density dependence (Fig. $1 \mathrm{~d} \rightarrow$ e).

While many economic activities should take the NDD form, some may produce an Allee-like functional relationship. In particular, subsistence strategies with an economy of scale can be described as Allee-like because everyone will do better with the addition of another individual. Forager subsistence strategies with an economy of scale include those where coordination pays off, such as fishing with nets (Bliege Bird and Bird, 1997), hunting large game (Smith, 1985; Alvard and Nolin, 2002), or driving game (e.g., Steward, 1938), and those that provide capital investments such as managing the land with fire (a form of landesque capital, see Bird et al., 2016; Gammage, 2011, also Lewis and Ferguson, 1988; Anderson, 2005), constructing fishing dams or weirs (Beckerman, 1983; Mohlenhoff and Codding, 2017), or building game drive lines and jumps (e.g., Frison, 2004; Hockett et al., 2013). However, because no subsistence activity scales indefinitely, eventually even

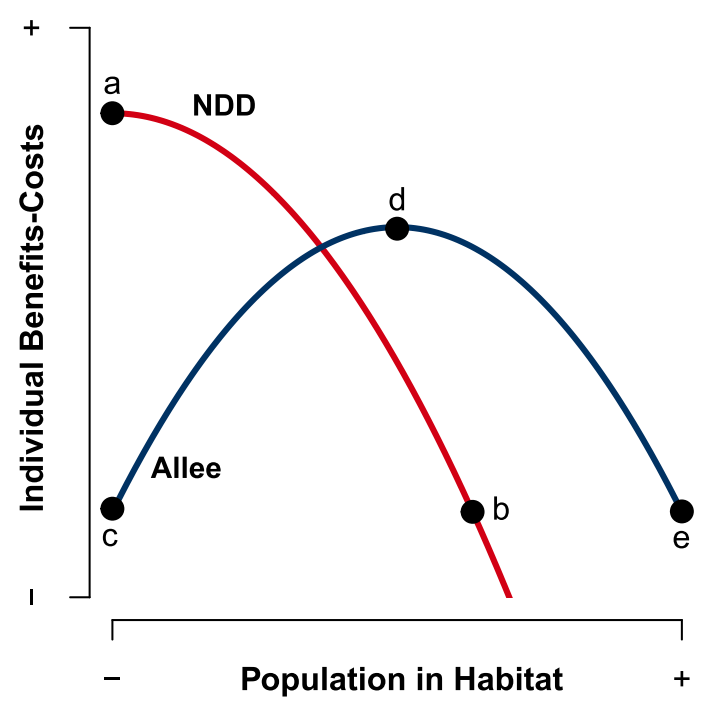

Fig. 1. Theoretical utility functions derived from the IDM (Greene and Stamps, 2001, eq. 1) describing the relationship between population size and utility (benefits minus costs) for subsistence strategies with negative density dependence (NDD) compared to those with an economy of scale resulting in Allee-like density dependence. Individuals engaged in NDD subsistence strategies would maximize utility by working alone, resulting in small cooperative groups with little common interest in engaging in territorial behavior. Individuals engaged in Allee-like subsistence strategies with an economy of scale should benefit from cohabitation, coordination, or cooperation, resulting in larger groups with shared interests in excluding others after saturation at the optimal group size (point d). an activity with an economy of scale will reach the saturation point at which everyone does worse with each additional joiner (e.g., Beckerman, 1983; Smith, 1985, 1991). This saturation threshold at the optimum group size-point $d$ in Fig. 1 - creates an incentive for individuals within a cooperative group to exclude others, whether they are would-be joiners or potential resource poachers; the latter having an incentive where economies of scale provide capital investments that increase resource profitability. Theory from the biological literature indicates that observed stable group sizes should be near (Kramer, 1985) or greater than the optimum (Sibly, 1983), the former being more likely if the shape of the Allee-like utility function begins with high per capita gains (Giraldeau and Gillis, 1985; Giraldeau, 1988, see review by Krause and Ruxton, 2002).

Of course, even if exclusion is beneficial at and after this saturation threshold, such behaviors should only be undertaken if the additional costs of excluding others is lower than the utility lost by allowing them to join. Whether or not this condition is met depends on at least two important factors. First, defense costs will lower the utility of the patch or activity for both the resident and the joiner (see Giraldeau, 1988, Fig. 3), but individuals attempting to join may have more to gain than the defender has to loose given the differential gains accrued by working alone (Fig. $1 \mathrm{c}$ ) versus working in a group (Fig. $1 \mathrm{~d}$ ). Thus for territoriality to emerge, the costs of exclusion must be high enough to discourage joiners, but lower than utility lost by simply allowing one more individual to enter the patch (Fig. $1 \mathrm{~d}+1$ ). Second, the per capita costs of exclusion will be dramatically lowered if every individual within the group shares some of the total cost of defense, but this introduces a social dilemma: everyone benefits from excluding potential joiners while the decision to pay the cost is up to every individual, thereby opening the door to the possibility of free-riders who gain the benefits of exclusion without paying the costs. Thus, to overcome this dilemma, individuals who pay the costs of excluding others must either gain differential benefits, which may take the form of increased social status or deference in decisions (Smith and Bliege Bird, 2005; Glowacki and von Rueden, 2015), or pay lower costs due to their innate abilities (Gilby et al., 2008), either of which may elicit further contributions from others (McAuliffe et al., 2015), and possibly facilitate larger groups with emergent leadership (Hooper et al., 2010).

Given the above, subsistence strategies with Allee-like utilitypopulation dynamics may present the ecological, economic, and social conditions that encourage territorial defense. Specifically, creating a context when individual economic interests are aligned to exclude others, thereby incentivizing territorial behavior-ranging from institutions of ownership to acts of violence and warfare. If this is correct, then individuals engaged in subsistence activities with an economy of scale should respond by forming larger cooperative groups of a size proportional to the marginal benefits gained from cooperating (see, e.g., Powers and Lehmann, 2017). In turn, these cooperative groups should eventually reach saturation, producing incentives for individuals to refuse potential in-group joiners and exclude out-group poachers as long as the costs of defense do not exceed the costs of adding another group member. This encourages territorial behaviors ranging from the development of institutions that limit others from within and outside the group from using claimed resources, to the deployment of physical violence needed enforce territorial claims threatened by out-group poachers or raiders. Thus we predict that if Allee-like economies of scale align individual interests in production tasks, then larger cooperative groups should have greater territorial behaviors manifested as higher levels of resource ownership and higher frequencies of inter-group violence.

Here we use ethnographic data on Western North American 
foragers compiled by Binford (2001) to evaluate the hypothesis that cooperative group size and territorial behaviors positively covary. If contact-era foragers in Western North America engaged in subsistence practices with an economy of scale, then they should have experienced Allee-like relationships between resource utility and population size. If this is true, then populations with larger cooperative groups would be encouraged to engage in increased territorial behaviors. In other words, and all else being equal, larger cooperative groups should have greater incentives and lower costs to refuse potential in-group joiners and exclude out-group users.

While we do not have data to examine economic utility (benefits minus costs) as a function of group size, we can evaluate how factors associated with territoriality-such as resource ownership and inter-group violence-scale with cooperative group size. If Western North American foragers engaged in subsistence practices with an Allee-like economy of scale, then stronger forms of territorial behavior should be associated with intermediate to large cooperative group sizes. Based on these predictions, we ask three questions with the available data: 1) Are larger cooperative groups more likely to own resource locations? 2) Do larger cooperative groups have higher levels of inter-group violence? 3) Do larger cooperative groups have higher levels of warfare?

\section{Methods}

\subsection{Data}

To evaluate our predictions, we rely on the global forager database compiled by Binford (2001). These data are available in print (Binford, 2001), on the web (Johnson, 2014), or as an R library (Marwick et al., 2016; R Core Team, 2016).

From the global forager database, we select populations from Western North America (Fig. 2). These include all populations designated to one of three culture areas (wc.area): Western North America ("WNA"), Northwest Coast ("BC NWC") or Southwest ("SW"), totaling 157 forager societies.

Binford (2001) flagged cases thought to be "suspect", indicating that they may have relied on some domesticated resources or had economies "based primarily on mutualistic articulations with nonhunting and gathering peoples" (Binford, 2001, p. 117). However, we do not exclude the six suspect populations in this sample in order to maintain the full range of variation described ethnohistorically, which may itself be a greater range of variation than

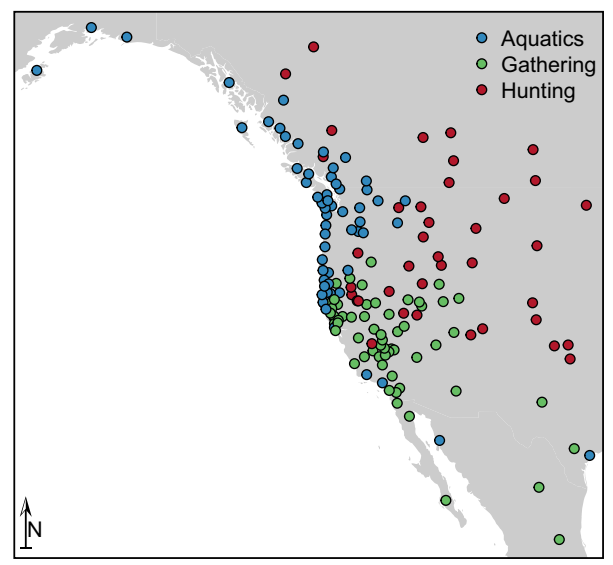

Fig. 2. Map of Western North American foragers represented in the Binford (2001) database color coded by the primary source of food (aquatic resources, gathered terrestrial plants, or hunted terrestrial animals). (For interpretation of the references to colour in this figure legend, the reader is referred to the web version of this article.) what existed prehistorically. We suggest that maintaining these populations in the sample more realistically represents the population dynamics that existed during this period of time, which represents post-contact equilibrium. Similarly, we include 24 populations described as "horse mounted hunters" (Binford, 2001, Table 7.06) so to reflect the diversity of adaptations represented across Western North America. However, to be sure that these latter cases are not primarily responsible for driving any of the results, we also evaluate each prediction for each major subsistence focus (more below).

For our purposes, two variables on group size are relevant (Binford, 2001, Table 8.01). The first (group1) is an estimate of the smallest self-sufficient group that regularly cooperates for subsistence during the most dispersed time of the year, here referred to as the minimum cooperative group size. Bettinger (2015) refers to this as the "microband". The second (group2) is an estimate of the average consumer group size during the most aggregated time of year, here referred to as the aggregated cooperative group size. The former (group1) can be thought of as the smallest possible cooperative group required for subsistence, while the latter (group2) can be thought of as the near largest cooperative group (Binford, 2001). Depending on variation in seasonal economic behaviors, the aggregated cooperative group may represent cooperative group size for nearly all of the year (for example, among sedentary populations along the Northwest Coast), or may represent aggregation events that are few and far between (for example, during rabbit drives in the Great Basin). The Western North American sample includes minimum cooperative group size estimates for 77 populations, and aggregated cooperative group size estimates for 138 populations. Here we assume that the group size values for each population represent the optimal outcome based on the local ecological and economic condition, essentially treating cooperative group size as a proxy for the Allee-like economy of scale present in the population. In this way, we follow Bettinger and Grote (2016, p. 83 ) by treating variables in the database as outcomes of "appropriate foraging decisions" relative to the local ecology and available resources. While this assumption cannot be tested with the current data, we defer to cases where it has been tested, such as among Bari where the optimal number of individuals in a cooperative fishing party is the same as the number of co-residing men (Beckerman, 1983), and among Inuit where “... foraging group size is guided by a desire to maximize per capita returns" (Smith 1991, p. 350), even when actual cooperative group sizes do not exactly conform to optimal expectations.

Our predictions suggest that these two measures of group size should covary with a number of additional attributes. First, we predict that the degree of resource ownership should increase with cooperative group size. For this Binford (2001, Table 9.01) provides an ordinal scale indicating the level of ownership of resource locations (owners) that ranges from one to four. Importantly, Freeman and Anderies (2015) note that these four categories do not clearly reflect a linearly increasing scale. A value of one indicates no ownership, values of two or three indicate that local groups claim resource ownership (resource locations generally vs. hunting and fishing locations specifically), and a value of four indicates elite ownership and some form of inheritance. As such, levels two and three may be considered equal, though we keep them distinct here.

Second, we predict that intergroup violence should increase with group size. Johnson (2014) reports an ordinal estimate of the scale of intergroup conflict (gpgpcon), which varies from one to four. The range of variation in intergroup violence includes: 1) none reported, 2) revenge raiding, 3) accelerative raiding, and 4) accelerative conflicts of annihilation.

Third, we predict that populations with larger cooperative groups should have higher levels of warfare. To evaluate this we use 
the variable on the scale and intensity of warfare (war1), which varies from one to five including: 1) no organized competition, 2) conflict is present off and on, 3) conflict is off and on more than category 2 and includes unprovoked attacks on intruders, 4) conflict is common with significant flare ups, to 5) conflict is sustained with the goal of long-term expansion (Johnson, 2014). While intergroup violence and warfare overlap, the later captures more formal and organized forms of violence.

Additionally, because the shape of the utility function (i.e., how the benefits-costs vary with group size) outlined in the proposed predictions may vary due to differences in the economy of scale associated with different forms of subsistence, we examine subsets of all the data based on whether the dominant source of food (subsp) comes from terrestrial plants ("Gathering"), terrestrial animals ("Hunting"), or aquatic resources ("Aquatics"). Out of the 157 total in our sample, 60 are focused on gathering terrestrial plants, 38 are focused on hunting terrestrial animals, and 59 are focused on aquatic resources.

Finally, one problem that requires attention is the possible nonindependence of variables derived from related populations. Known as Galton's Problem (Tylor, 1889), non-independence could bias the results if a number of individual cases have similar values as a result of historical transmission from a common source, which could lead a historical cause to be conflated for functional cause. We account for this statistically (see below) using the phylogenetic language classification (phyl) (Johnson, 2014) derived from Ethnologue (Lewis et al., 2009), tagging each case by its most generic linguistic phylum, often referred to as the language family. The data include 17 language families: Algic, Chimakuan, Chumash, Coahuiltecan, Eskimo-aleut, Guacurian, Hokan, Kiowa Tanoan, Kutenai, Na-dene, Oto-manguean, Penutian, Salishan, Siouan, Uto-aztecan, Wakashan, and Yuki. All of these variables are summarized in Table 1.

\subsection{Statistical methods}

To evaluate the predictions outlined above, we rely on generalized additive models (Wood, 2006). Just as generalized linear models extend ordinary least squares regression to data with nonnormally distributed errors (Faraway, 2006), generalized additive models extend linear models further by allowing for a non-linear response between predictor and response variables. Because these models do not force a functional relationship between variable sets, they allow the data to "speak for themselves".

Analyses are run in the R environment (R Core Team, 2016) using the mgcv library (Wood, 2012). Models assume a poisson distribution based on the count (e.g., number of people) or count-like (e.g., ordinal levels of ownership) nature of the variables, and rely on quasi-likelihood estimation to avoid over dispersion.
To account for the problem of non-independence (i.e., Galton's Problem), we use generalized additive mixed models (GAMM) and include the language phylogeny as a random effect. This allows us to evaluate the results while removing the potential effect of historical relatedness (see, e.g., Currie and Mace, 2009; Nettle, 2009).

All model results report the sample size (n), the estimated degrees of freedom (edf), the f-statistic $(f)$, the $r^{2}$ value, and the $p$ value. Interpretation of the results rely on an examination of the amount of variance in the response variable explained by the predictor variable $\left(r^{2}\right)$ and the probability that the relationship is a false positive ( $p$ value).

\section{Results}

3.1. Question 1: are larger cooperative groups more likely to own resource locations?

The scale of resource ownership initially increases significantly with the minimum cooperative group size $\left(r^{2}=0.13, p=0.0026\right)$ and the aggregated cooperative group size $\left(r^{2}=0.11, p=0.0003\right.$; see Table 2), however both of these relationships are non-linear (Fig. 3). Ownership increases with the minimum cooperative group up to approximately 35 individuals, and begins to decline after about 40 individuals. This decline is driven by several populations of horse mounted hunters (e.g., Blackfoot, Assiniboin, Crow) who have large groups, but limited ownership of resource patches. Resource ownership increases with the aggregated cooperative group size, leveling off after approximately 400 individuals. This suggests that there is a diminishing return to ownership as a function of group size. These trends hold when language family is included as a random effect (Table 2), showing that the results are not biased by the non-independent history of related populations.

Examining each subsistence category independently reveals no meaningful relationship between group size and ownership among hunting-oriented populations, while both gathering- and aquaticoriented populations reveal strong positive associations between group size an ownership (Table 2 ).

Among the subset of gathering populations, Owens Valley Paiute have the largest minimum cooperative group size and, along with California societies such as Nomlaki and Lake Miwok, maintain the highest level of ownership (3) present in this subsample. These populations all share an intensive focus on tree nuts (pine nuts or acorns), which likely have an economy of scale. Likewise, Mono (or Monachi), an intensive acorn gathering population in the Sierra Nevada, have the largest aggregated cooperative group size and highest level of ownership (4), followed by other intensive acorn economies such as the Serrano and Diegueno, and by the pine nut-reliant Owens Valley Paiute in the

Table 1

\begin{tabular}{lll} 
Summary of variables. & & \\
\hline Variable & Description & Role \\
\hline $\begin{array}{l}\text { Minimum cooperative } \\
\text { group size (group1) }\end{array}$ & $\begin{array}{l}\text { smallest self-sufficient group that regularly } \\
\text { cooperates for subsistence during } \\
\text { the most dispersed time of the year } \\
\text { average consumer group size during } \\
\text { the most aggregated time of year } \\
\text { ownership of resource locations }\end{array}$ & predictor \\
$\begin{array}{l}\text { Aggregated cooperative } \\
\text { group size (group 2) }\end{array}$ & count \\
$\begin{array}{l}\text { Resource ownership } \\
\text { (owners) }\end{array}$ & scale of intergroup violence \\
$\begin{array}{l}\text { Intergroup violence } \\
\text { Warfare (war1) }\end{array}$ & $\begin{array}{l}\text { scale and intensity of warfare } \\
\text { Subsistence (subsp1) } \\
\text { Phylogeny (phyl) }\end{array}$ & ordinal (1-4) \\
\hline
\end{tabular}


Table 2

Summary of generalized additive model results testing each of the three predictions.

\begin{tabular}{|c|c|c|c|c|c|c|c|c|c|c|}
\hline \multirow[t]{2}{*}{ P\#) Variable } & \multicolumn{5}{|c|}{ Minimum Cooperative Group } & \multicolumn{5}{|c|}{ Aggregated Cooperative Group } \\
\hline & $\mathrm{n}$ & edf & $f$ & $r^{2}$ & $p$ & $\mathrm{n}$ & edf & $f$ & $r^{2}$ & $p$ \\
\hline P1) Resource Ownership & 77 & 1.9 & 7.08 & 0.13 & 0.0026 & 138 & 1.7 & 10.47 & 0.11 & 0.0003 \\
\hline P1) Resource Ownership ${ }^{a}$ & 77 & 1.72 & 5.42 & 0.09 & 0.0395 & 138 & 1.57 & 9.25 & 0.10 & 0.0042 \\
\hline P1) Ownership: Hunting & 30 & 1.0 & 1.66 & 0.02 & 0.2080 & 34 & 1.0 & 2.07 & 0.03 & 0.1600 \\
\hline P1) Ownership: Gathering & 35 & 1.0 & 7.55 & 0.17 & 0.0096 & 53 & 1.0 & 13.87 & 0.20 & 0.0005 \\
\hline P1) Ownership: Aquatics & 12 & 1.0 & 9.44 & 0.48 & 0.0114 & 51 & 1.8 & 5.16 & 0.15 & 0.0177 \\
\hline P2) Intergroup Violence & 77 & 1.9 & 26.36 & 0.43 & $<0.0001$ & 138 & 1.9 & 30.16 & 0.30 & $<0.0001$ \\
\hline P2) Intergroup Violence ${ }^{a}$ & 77 & 1.84 & 14.83 & 0.419 & $<0.0001$ & 138 & 1.86 & 16.34 & 0.28 & $<0.0001$ \\
\hline P2) Violence: Hunting & 30 & 1.8 & 11.36 & 0.46 & 0.0004 & 34 & 1.8 & 9.73 & 0.37 & 0.0010 \\
\hline P2) Violence: Gathering & 35 & 1.0 & 4.80 & 0.11 & 0.0354 & 53 & 1.9 & 13.78 & 0.35 & $<0.0001$ \\
\hline P2) Violence: Aquatics & 12 & 1.0 & $<0.01$ & $<0.01$ & 0.9370 & 51 & 1.4 & 8.59 & 0.19 & 0.0040 \\
\hline P3) Warfare & 77 & 1.9 & 20.59 & 0.34 & $<0.0001$ & 138 & 1.9 & 28.45 & 0.28 & $<0.0001$ \\
\hline P3) Warfare ${ }^{a}$ & 77 & 1.80 & 13.89 & 0.33 & 0.0001 & 138 & 1.84 & 20.15 & 0.28 & $<0.0001$ \\
\hline P3) Warfare: Hunting & 30 & 1.8 & 14.66 & 0.49 & $<0.0001$ & 34 & 1.0 & 30.61 & 0.51 & $<0.0001$ \\
\hline P3) Warfare: Gathering & 35 & 1.0 & 10.20 & 0.21 & 0.0030 & 53 & 1.8 & 10.49 & 0.28 & 0.0004 \\
\hline P3) Warfare: Aquatics & 12 & 1.0 & 0.12 & $<0.01$ & 0.7390 & 51 & 1.8 & 9.44 & 0.24 & 0.0009 \\
\hline
\end{tabular}

a Model controls for linguistic relatedness (language family) as a random effect.

\section{Great Basin.}

The strongest association between group size and ownership is among the subset of aquatic foragers, with whom $48 \%$ of the variance in resource ownership is explained by the minimum cooperative group (Table 2). The three largest aggregated cooperative groups with the highest level of ownership (see Fig. 3, right frame, top right of plot) are all from the Northwest Coast: Haida, Kwakiutl, and Tsimshim. Two other aquatic focused populations, the Haisla and Chumash, have equally large or larger aggregated groups with the next highest scale of resource ownership indicating owned hunting or fishing grounds.

\subsection{Question 2: do larger cooperative groups have higher levels of inter-group violence?}

Larger cooperative groups tend to have increased levels of intergroup violence (Table 2). The scale of intergroup violence increases significantly with the minimum cooperative group size up to approximately 45 individuals $\left(r^{2}=0.43, p<0.0001\right)$, and with the aggregated cooperative group up to approximately 350 individuals $\left(r^{2}=0.30, p<0.0001\right)$, plateauing thereafter in both cases (Fig. 4). As with resource ownership, these trends hold when controlling for phylogenetic relatedness (Table 2).

Much of the variation in intergroup violence explained by the minimum cooperative group size is driven by hunting focused populations, for which the relationship holds strong when examined alone $\left(r^{2}=0.46, p<0.0001\right)$. The relationship also holds with gathering focused groups $\left(r^{2}=0.11, p=0.0354\right)$, but the minimum cooperative group size does not explain variation in violence among aquatic focused populations $\left(r^{2}<0.01, p=0.9370\right)$.

The scale of intergroup violence increases significantly with the aggregated cooperative group size among all subsistence groups independently (Table 2). Aggregated group size accounts for $37 \%$, $35 \%$ and $19 \%$ of the variance in ordinal violence among hunting, gathering, and aquatic oriented foragers respectively. Among gathering populations, California societies have the highest conflict-group size combinations, including the Serrano, Diegueno, and Southern Pomo. Overall, Northwest Coast populations focused on aquatic resources such as the Haisla and Haida have the largest aggregated cooperative group sizes, and the highest levels of intergroup violence.

\subsection{Question 3: do larger cooperative groups have higher levels of warfare?}

The scale and intensity of warfare increases significantly with the minimum cooperative group size $\left(r^{2}=0.34, p<0.0001\right)$ and the aggregated cooperative group size $\left(r^{2}=0.28, p<0.0001\right)$,
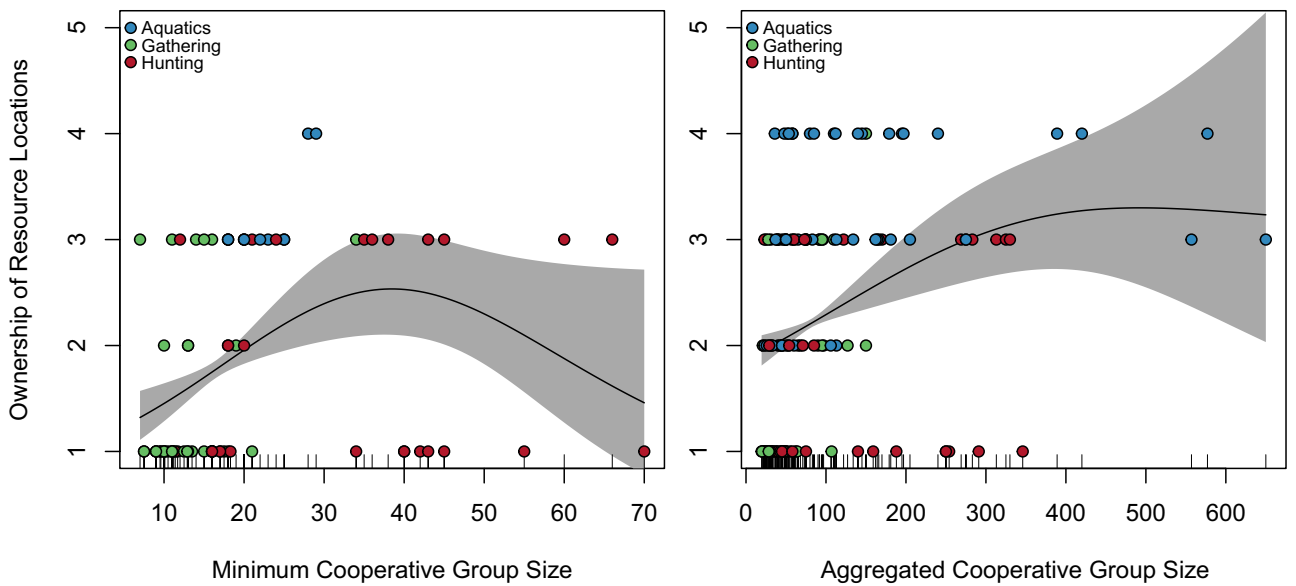

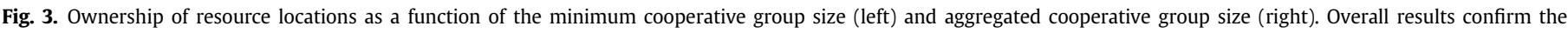
prediction that larger corporate groups have higher levels of resource ownership. 

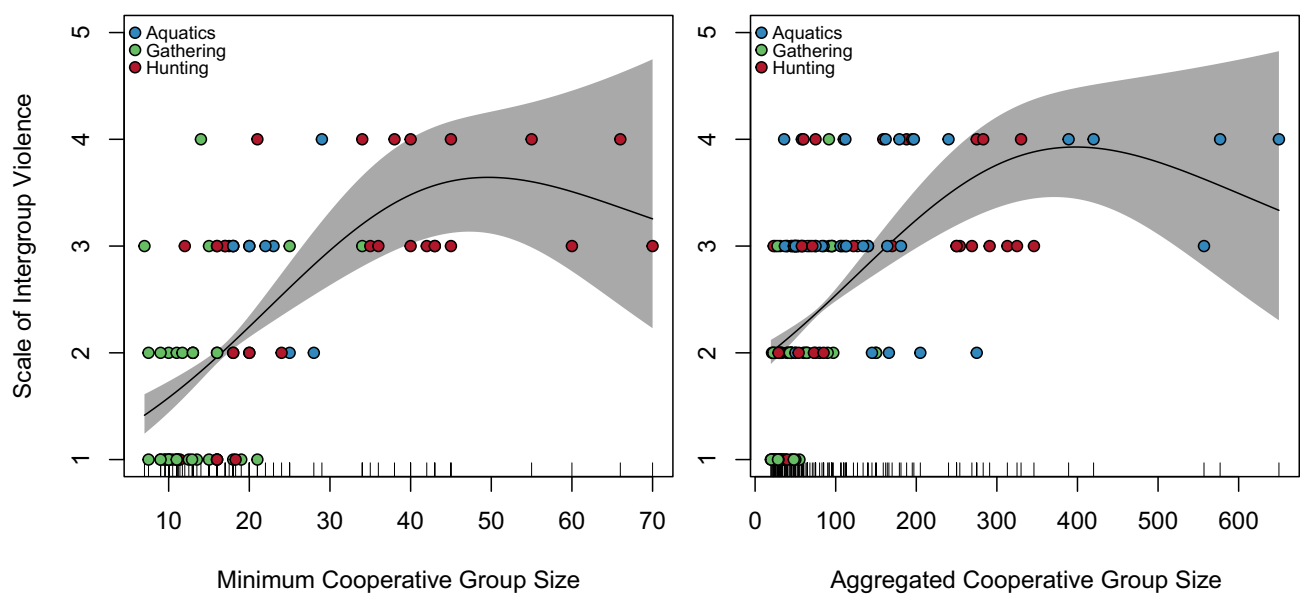

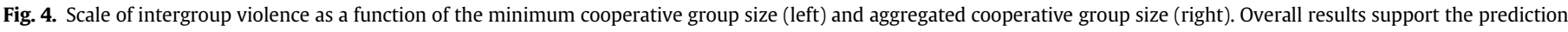
that larger corporate groups have greater levels of violence.

plateauing at approximately 45 individuals and 400 individuals respectively (Fig. 5). These trends remain robust even when accounting for shared linguistic ancestry (Table 2).

The relationship between the minimum cooperative group size and warfare holds for hunting $\left(r^{2}=0.49, p<0.0001\right)$ and gathering $\left(r^{2}=0.21, p=0.0030\right)$ focused populations, but not for populations relying on aquatic resources $\left(r^{2}<0.01, p=0.7390\right)$. Of gatheringfocused populations, those with the highest levels of warfare have economies focused on tree nuts, such as the Lake Miwok and Owens Valley Paiute. Overall, the largest minimum cooperative groups with the most warfare are all horse-mounted hunting populations including the Blackfoot, Crow, and Comanche.

The significant effect of the aggregate cooperative group size on the scale and intensity of warfare holds for all subsistence categories (Table 2), explaining as much as $51 \%$ of the variance for hunting populations and as little as $24 \%$ for aquatic oriented populations. The hunting-focused populations with large aggregated groups and high levels of warfare are all horse mounted hunters, including the Arapaho, Blackfoot, Crow, and Kiowa. Plant gathering populations with large aggregated cooperative groups and high levels of warfare again include tree nut (acorn) focused populations such as the Serrano, Monachi, and Southern Pomo. Aquatic-focused populations on the Northwest Coast, including the Haida, Tsimshim, Kwakiutl, and Haisla, have the highest warfare-aggregate group size combinations overall.

\section{Discussion}

\subsection{Summary of results}

Overall, the results uphold our predictions indicating positive covariance between cooperative group size and territorial behaviors. Given our theoretical assumptions, we suggest these relationships result from Western North American foragers engaging in subsistence strategies with economies of scale that created Alleelike relationships between utility and population size. While this relationship itself cannot be tested with these data, the results are consistent with our expectations and suggest areas for future research.

However, despite the overall support of our predictions, there is variation across subsistence types that illustrates a nuanced relationship between cooperative group size and territorial behavior. The results indicate that increased cooperative group size leads to greater resource ownership only among gathering and aquatic focused foragers, but not among hunting focused foragers. This likely results from the high residential mobility of hunting groups, itself driven by the dense yet unpredictable nature of their resource base, which as Dyson-Hudson and Smith (1978) illustrate,
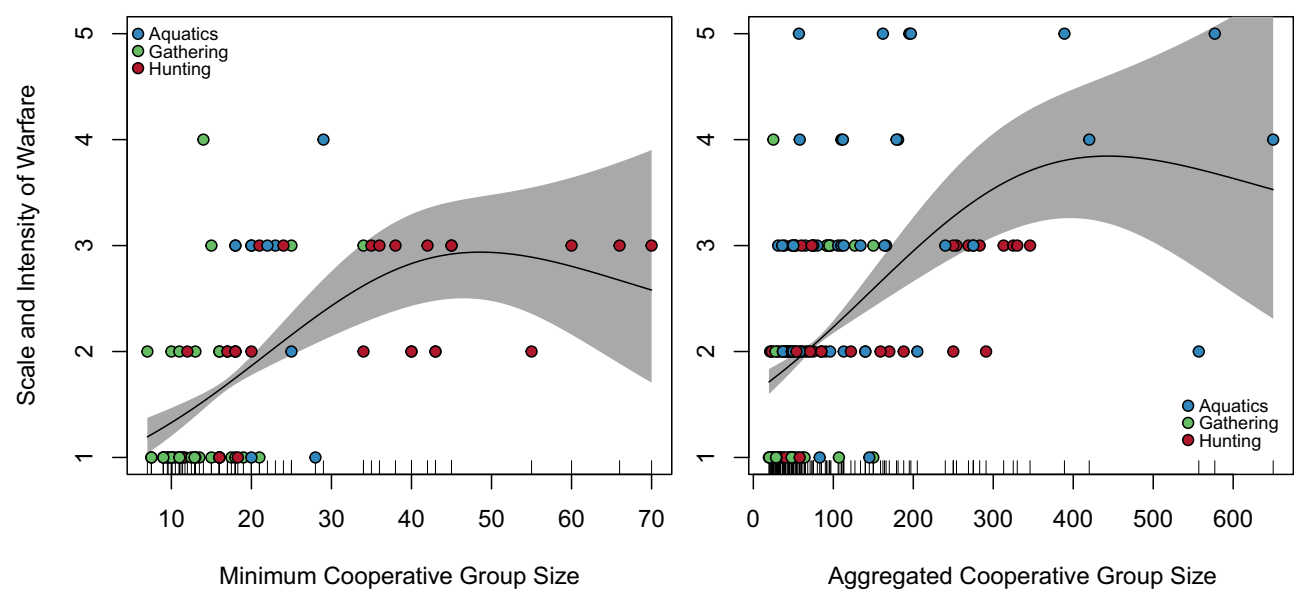

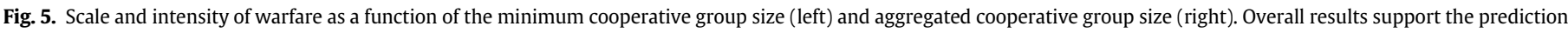
that larger corporate groups have greater levels widespread regional conflict. 
precludes economic defendability.

While violence and warfare increase with the minimum cooperative group size among hunting and gathering populations, the relationship does not hold among aquatic focused populations. This may result from the limited number of aquatic groups for which minimum cooperative group size estimates are available, itself perhaps a telling indicator that the measure has little meaning with sedentary or semi-sedentary populations like those on the Northwest Coast who live in densely aggregated groups year round due to the dense and predictable nature of their resource base (DysonHudson and Smith, 1978).

The low extreme combinations of group size and territorial behavior are dominated by terrestrial plant gathering populations. But it is important to note that each of the predicted relationships between group size and territorial behavior holds when examined among terrestrial plant gatherers independently. This indicates that variation in territorial behavior, even among populations focused on terrestrial plants, may be driven by increasing economies of scale that lead to Allee-like dynamics. With plants, such economies of scale are likely motivated either by capital investments (such as burning, or sowing seeds, Freeman and Baggio, 2017, this issue), by improving efficiency in collecting resources over a short harvest window (Morgan, 2012), or by technological innovations that reduce processing time (Hawkes and O'Connell, 1992). In the current sample, these trends seem most apparent with tree nut economies.

The high extreme combinations are represented by highly mobile horse-mounted hunting populations for the minimum cooperative group size, and by sedentary Northwest Coast aquatic focused populations for the aggregate cooperative group size. That horse mounted groups have the largest minimum cooperative groups suggests that the adoption of the horse brings an economy of scale that necessitates coordinated hunting. That aquatic focused populations have the largest aggregated cooperative groups suggests that there are limited benefits of fissioning in order to exploit more dispersed resources.

While the results may be driven by other trade-offs experienced by Western North American hunter-gatherer populations, we suggest these findings are consistent with the theoretical assumption that Allee-like economies of scale drive the formation of larger cooperative groups who find territorial behaviors worthwhile.

\subsection{Individuals, groups, free riders and defenders}

The IDM examined here has the benefit of generating testable predictions about how individuals should respond to specific contexts, and how those decisions will look in aggregate (Sutherland, 1996). Importantly, rather than thinking that larger cooperative groups have more resource ownership, violence, and warfare simply because they can, here we suggest that these institutions and strategies emerge not only from the ability of larger groups, but from individual self interest that is more or less aligned at or near optimal cooperative group size (Fig. 1d). This also shows that no appeal to the problematic (see Williams, 1966) theory of group selection is necessary to account for these patterns ( $c f$. Bowles, 2009).

However, it would be unrealistic to think that the interests of individuals would be completely aligned so to overcome the social dilemma present in territorial defense. Individuals who pay the cost of defense provide a benefit that is shared among everyone. If too few people are willing to pay those costs, then the burden of defense will be too great and territorial behaviors will collapse, or never emerge in the first place. Hence why some suggest that collective behaviors require punishment (e.g., Mathew and Boyd,
2011) to ensure enough of the population pays the cost for the collective good. But punishment is itself a second-order collective action problem that necessitates some differential benefit to the punisher (e.g., Fehr and Gächter, 2002). Hence why we suggest that defenders must either pay lower costs, or must receive additional benefits. For example, some individuals may be inherently better at excluding others so that they incur only a fraction of the costs compared to the average person. Individual defenders may also gain differential benefits from their pro-social behavior (Smith and Bliege Bird, 2005), possibly emerging as leaders who coordinate defense (Glowacki and von Rueden, 2015) or reprisals (Glowacki et al., 2016) and gain material rewards or social position as a result. Further, the contribution of a few may elicit more contributions from others leading to a higher proportion of defenders (McAuliffe et al., 2015). Though no matter how low the cost or high the rewards, we expect that some proportion of the population will always free ride, but as long as they are few enough that those paying the costs of territorial defense do a bit better through their collective efforts, then those free riders should be tolerated (Blurton Jones, 1984, 1987). With these dynamics in mind, we suggest that the model presented here illustrates the conditions that create just enough of an alignment in self interest to raise the proportion of defenders above some threshold that makes cooperative defense worthwhile.

\subsection{Intensification, economies of scale, and property rights}

Our findings support the idea that there is a link between cooperative group size and territorial behaviors, which we suggest is driven by Allee-like economies of scale. But these findings also raise the question of what produces an economy of scale in the first place. One possible explanation is that economic intensification (sensu stricto, see Morgan, 2015) may underlie the emergence of economic activities that scale with additional labor inputs. Intensive economies are those that yield higher returns per unit area, but at a higher overall cost (Boserup, 1965). From the perspective of optimal foraging theory, specifically the prey choice model (Charnov, 1976), intensification results from a decline in the encounter rate with high return resources, to which individuals optimally respond by widening their diet breadth to include lower ranked resources that require greater amounts of time spent in pursuit and/or processing (see examples in Bird and O'Connell, 2006; Codding and Bird, 2015). Because such resources are often abundant, but require increased handling time, individuals will benefit from anything that increases pursuit or processing efficiency (Hawkes and O'Connell, 1992), including any form of cooperation that increases per capita gains.

Cooperative labor may be particularly important if the availability of these intensive resources is seasonally synchronous, such as anadromous fish or tree nuts, which require individuals to capture, and possibly process, large amounts of food over a relatively short period of time in order to store enough for other parts of the year. Several events in Western North American prehistory seem to support this hypothesis, including the transition to intensive salmon economies on the Northwest Coast of California (Tushingham and Bettinger, 2013, 2017, this issue), the emergence of acorn economies throughout California (Gifford, 1936; McCarthy, 1993; Codding and Jones, 2016; Stevens et al., 2017, this issue) and the shift to intensive green cone pine nut processing in the Great Basin (Bettinger and Baumhoff, 1982; Magargal et al., 2017). Each of these subsistence transitions represent an economic shift toward a more intensive resource that may have an economy of scale, and results in increased territorial behavior. If Allee effects are the driver of these patterns, then the optimal size of a cooperative group and the scale of territorial behaviors may be predictable 
based on the ecological conditions that structure the local economy of scale. In the Great Basin, such differences are seen comparing Shoshone, who operated in smaller cooperative groups over smaller territories and had family level ownership of grass seed locations, with the Northern Paiute, who operated in larger cooperative groups over larger territories and had band level ownership of pine nut tracts (Parker et al., 2017, this issue).

While previous work suggests that property rights and intensive economies necessarily co-evolve (Bowles and Choi, 2013; Freeman and Baggio, 2017, this issue), here we offer the intermediate step that such intensive economies may facilitate the emergence of territorial behavior if they provide an Allee-like economy of scale. If this is generally true, then where intensive economic shifts occur, we should expect to see individuals close the commons (sensu Ostrom, 1990) at a size and scale proportional to the optimal cooperative group size generated by the particular economy of scale.

\subsection{Violence, warfare and territoriality}

Violence was common across North America, but with significant variation between populations (Lambert, 2002; Chacon and Mendoza, 2007; Allen and Jones, 2014; Allen et al., 2016). The findings outlined above suggest that this variation in the frequency and scope of intergroup aggression may result at least in part from the size of the optimal cooperative group, which itself may be driven by Allee effects that produce an economy of scale and facilitate in-group cooperation to exclude others.

Our interpretation is in line with long-standing anthropological theories that see intergroup violence as an adaptive response to particular ecological circumstances, such as increasing competition for scarce resources (Durham, 1976). Here, however, we extend this model of violence to suggest that just as property rights may coevolve with intensive economies of scale, so may intergroup aggression grow with Allee-like benefits to cooperation. If this is true, then factors that precipitate violence, such as resource scarcity (Allen et al., 2016), may have a greater effect when populations are engaged in the exploitation of intensive resources that facilitate cooperative economic endeavors.

The archaeological record for North America provides some support for this conclusion. For example, Moss and Erlandson (1992) suggest that the proliferation of defensive sites approximately 1000 years ago in the North Pacific may be associated with increased resource stress among a relatively large population focused on intensive fishing, making it critical to exclude others. Despite lacking clear defensive structures (Lambert, 2002) the prehistoric record in California also provides examples where variation in violence seems to be linked to territoriality (Bartelink et al., 2013; Lambert, 1997; Schwitalla et al., 2014). Of note, osteological evidence of violence the Santa Barbara Channel region is associated with an increase in population size, fishing intensity, climate change, and territorial formation (Walker, 1989; Lambert, 1997, 2002; Kennett and Kennett, 2000; Kennett et al., 2009; Jazwa et al., 2017, this issue), again suggesting a link between Allee-like economies and competition that may drive exclusionary behavior at or beyond the optimal group size.

Ethnographic data too offer some support for this framework. Tushingham and Bettinger (2017, this issue) show that Northwest Coast populations reliant on intensive "front loaded" resources requiring up front processing have larger cooperative groups operating at higher densities producing expansive territorial behavior. In California, Bettinger (2015) argues that smaller, but more cohesive cooperative groups known as "Tribelets" (Kroeber, $1925,1955)$ formed through a process of intensification focused on acorns, and later small seeds, encouraging kin-based territorial ownership over plant resource patches.

\subsection{Conditions for despotism?}

This paper proposes that Allee-like effects generate an economy of scale which may establish the foundations for overcoming the within-group collective action problems associated with limiting group size, which also promotes between-group boundary formation possibly leading to conflict. As such, this framework outlines the conditions wherein egalitarian populations who are "free" to settle where they like, may become constrained by others who have an interest in limiting group size. While this transition to a "despotic" settlement pattern has been used to explain the origins of social inequality (e.g., Winterhalder et al., 2010; Prufer et al., 2017; Jazwa et al., 2017, this issue), here, we propose that Alleelike economies of scale may provide a mechanism that facilitates this transition.

As discussed above, individuals who are able to successfully limit group size may emerge as leaders who gain differential benefits. If the benefits grant leaders with greater resource holding potential (Boone, 1992) or favorable reproductive skew (Vehrencamp, 1983; Summers, 2005), then they may gain sustained dominance over others. This may further lead to persistent institutionalized inequality if resource patches are defensible and inherited (Mattison et al., 2016). This situates our framework within existing models for the origins of inequality, providing a link connecting processes of economic intensification to social inequality. If this is true, then the emergence of Allee-like economies of scale may inadvertently generate the foundations that allow despotic behavior to emerge, leading to inequality.

\section{Conclusion}

Here we suggest that Allee's principle helps to explain how territorial behaviors can emerge as artifacts of the individual benefits gained from aggregations in ecological contexts where economic returns to scale make in-group cooperation and out-group exclusion worthwhile. As our results only evaluate the relationship between group size and territorial behaviors, additional ethnographic work is needed to confirm our theoretical assumptions linking Allee-like economies of scale and larger optimal group size. Nonetheless, the results presented here offer an ethnographic validation of what we argue are the consequences of this general model of human behavior, specifically showing that cooperative group size and territorial behaviors positively covary. We hope this encourages future work on the topic, including archaeological evaluations of this model to determine how the linkages between intensive Allee-like economies of scale and territoriality developed in the past.

\section{Acknowledgments}

Duncan Metcalfe was instrumental in the development of this theoretical approach. Many of the ideas outlined here were informed by discussions with Jim O'Connell and Chris Parker. Amber Johnson provided detailed answers to queries on the Binford variables, and Cody Haisley provided assistance in evaluating the data. Thanks to Nathan Stevens and Adie Whitaker for supporting this undertaking and providing helpful comments on an earlier version of this paper. Two anonymous reviewers, Kristen Hawkes, Kurt Wilson, Kenneth Blake Vernon, and others in the University of Utah Archaeological Center lab group offered substantive comments that greatly improved the final paper. This research did not receive any specific grant from funding agencies in the public, commercial, or not-for-profit sectors. 


\section{Appendix A. Supplementary data}

Supplementary data related to this article can be found at https://doi.org/10.1016/j.quaint.2017.10.045.

\section{References}

Allee, W.C., 1931. Animal Aggregations, a Study in General Sociology. The University of Chicago Press.

Allen, J., O'Connell, J.F., 2008. Getting from Sunda to Sahul, In: Clark, G., Leach, F. O'Connor, S. (Eds.), Islands of Inquiry: Colonization, Seafaring and the Archaeology of Maritime Landscapes. ANU E Press, Australian National University, Canberra, pp. 31-46.

Allen, M.W., Bettinger, R.L., Codding, B.F., Jones, T.L., Schwitalla, A.W., 2016. Resource scarcity drives lethal aggression among prehistoric hunter-gatherers in central California. Proc. Natl. Acad. Sci. 113, 12120-12125.

Allen, M.W., Jones, T.L. (Eds.), 2014. Violence and Warfare Among Hunter-Gatherers Left Coast Press.

Alvard, M.S., Nolin, D.A., 2002. Rousseaus whale hunt? Curr. Anthropol. 43 (4), $533-559$.

Anderson, M.K., 2005. Tending the Wild: Native American Knowledge and the Management of California's Natural Resources. University of California Press, Berkeley.

Bartelink, E. Andrushko, V.A., Bellifemine, V. Nechayev, I., Jurmain, R., 2013. Violence and warfare in the prehistoric San Francisco Bay Area, California: regional and temporal variations in conflict. In: Knusel, C., Smith, M. (Eds.), The Routledge Handbook of the Bioarchaeology of Human Conflict. Taylor and Francis, Oxford, pp. 285-307.

Beckerman, S., 1983. Optimal foraging group size for a human population: the case of Bari fishing. Am. Zool. 23 (2), 283-290.

Bell, A.V., Winterhalder, B., 2014. The population ecology of despotism. Hum. Nat. 25 (1), 121-135.

Bettinger, R.L., 2015. Orderly Anarchy: Sociopolitical Evolution in Aboriginal California. Univeristy of California Press, Berkeley.

Bettinger, R.L., Baumhoff, M.A., 1982. The Numic spread: Great Basin cultures in competition. Am. Antiq. 47, 485-503.

Bettinger, R.L., Grote, M.N., 2016. Marginal value theorem, patch choice, and human foraging response in varying environments. J. Anthropol. Archaeol. 42, 79-87.

Binford, L.R., 2001. Constructing Frames of Reference. University of California Press Berkeley.

Bird, D.W., Bird, R.B., Codding, B.F., Taylor, N., 2016. A landscape architecture of fire: cultural emergence and ecological pyrodiversity in Australia's Western Desert. Curr. Anthropol. 57 (S13), S65-S79.

Bird, D.W., O'Connell, J.F., 2006. Behavioral ecology and archaeology. J. Archaeol Res. 14, 143-188. https://doi.org/10.1007/s10814-006-9003-6.

Bliege Bird, R., Bird, D.W., 1997. Delayed reciprocity and tolerated theft: the behavioral ecology of food sharing strategies. Curr. Anthropol. 38, 49-78.

Blurton Jones, N.G., 1984. A selfish origin for human food sharing: tolerated theft. Evol. Hum. Behav, 5, 1-3.

Blurton Jones, N.G., 1987. Tolerated theft, suggestions about the ecology and evolution of sharing, hoarding and scrounging. Soc. Sci. Inf. 26 (1), 31-54.

Boone, J.L., 1992. Competition, conflict, and the development of social hierarchies. In: Smith, E.A., Winterhalder, B. (Eds.), Evolutionary Ecology and Human Behavior. Aldine de Gruyter, New York, pp. 301-337.

Borgerhoff Mulder, M., 1990. Kipsigis women's preferences for wealty men: evidence for female choice in mammals. Behav. Ecol. Sociobiol. 27, 255-264.

Boserup, E., 1965. The Conditions of Agricultural Growth: the Economics of Agrarian Change under Population Pressure. Aldine, Chicago, Illinois.

Bowles, S., 2009. Did warfare among ancestral hunter-gatherers affect the evolution of human social behaviors? Science 324 (5932), 1293-1298.

Bowles, S., Choi, J.-K., 2013. Coevolution of farming and private property during the early Holocene. Proc. Natl. Acad. Sci. 110, 8830-8835.

Cashdan, E., 1983. Territoriality among human foragers: ecological models and an application to four Bushman groups. Curr. Anthropol. 24, 47-66.

Chacon, R.J., Mendoza, R.G., 2007. North American Indigenous Warfare and Ritual Violence. University of Arizona Press.

Charnov, E.L., 1976. Optimal foraging: attack strategy of a mantid. Am. Nat. 110, $141-151$.

Codding, B., Bird, D., Jones, T., 2012. A land of work: foraging behavior and ecology. In: Jones, T.L., Perry, J.E. (Eds.), Contemporary Issues in California Archaeology. Left Coast Press, Walnut Creek.

Codding, B.F., Bird, D.W., 2015. Behavioral ecology and the future of archaeological science. J. Archaeol. Sci. 56, 9-20.

Codding, B.F., Jones, T.L., 2013. Environmental productivity predicts migration, demographic and linguistic patterns in prehistoric California. Proc. Natl. Acad. Sci. $110,14569-14573$.

Codding, B.F., Jones, T.L., 2016. External impacts on internal dynamics: effects of paleoclimatic and demographic variability on acorn exploitation along the central California coast. In: Contreras, D. (Ed.), The Archaeology of Humanenvironment Interactions: Strategies for Investigating Anthropogenic Landscapes, Dynamic Environments, and Climate Change in the Human Past. Routledge, pp. 195-210.

Courchamp, F., Clutton-Brock, T., Grenfell, B., 1999. Inverse density dependence and the Allee effect. Trends Ecol. Evol. 14 (10), 405-410.

Currie, T.E., Mace, R., 2009. Political complexity predicts the spread of ethnolinguistic groups. Proc. Natl. Acad. Sci. 106 (18), 7339-7344.

Disma, G., Sokolowski, M.B., Tonneau, F., 2011. Children's competition in a natural setting: evidence for the ideal free distribution. Evol. Hum. Behav. 32 (6), 373-379.

Durham, W.H., 1976. Resource competition and human aggression, part i: a review of primitive war. Q. Rev. Biol. 51 (3), 385-415.

Dyson-Hudson, R., Smith, E.A., 1978. Human territoriality: an ecological reassessment. Am. Anthropol. 80, 21-41.

Faraway, J., 2006. Extending the Linear Model with R: Generalized Linear, Mixed Effects and Nonparametric Regression Models. Chapman and Hall, New York.

Fehr, E., Gächter, S., 2002. Altruistic punishment in humans. Nature 415 (6868), $137-140$.

Freeman, J., Anderies, J.M., 2015. A comparative ethnoarchaeological analysis of corporate territorial ownership. J. Archaeol. Sci. 54, 135-147.

Freeman, J., Baggio, J., 2017. The effect of ownership on ecosystem management among human foragers. Quat. Int.

Fretwell, S.D., Lucas, H.L., 1969. On territorial behavior and other factors influencing habitat distribution in birds I. theoretical development. Acta Biotheor. 19, $16-36$.

Frison, G., 2004. Survival by Hunting: Prehistoric Human Predators and Animal Prey. Univ of California Press.

Gammage, B., 2011. The Biggest Estate on Earth: How Aborigines Made Australia. Allen and Unwin, Sydney.

Gifford, E.W., 1936. Californian balanophagy. In: Lowie, R. (Ed.), Essays Presented to A. L. Kroeber. University of California Press., Berkeley, pp. 87-98.

Gilby, I.C., Eberly, L.E., Wrangham, R.W., 2008. Economic profitability of social predation among wild chimpanzees: individual variation promotes cooperation. Anim. Behav. 75 (2), 351-360.

Giovas, C.M., Fitzpatrick, S.M., 2014. Prehistoric migration in the Caribbean: past perspectives, new models and the ideal free distribution of West Indian colonization. World Archaeol. 46 (4), 569-589.

Giraldeau, L.-A., 1988. The stable group and the determinants of foraging group size. In: Meurant, G. (Ed.), The Ecology of Social Behavior. Academic Press New York, pp. 33-53.

Giraldeau, L.-A., Gillis, D., 1985. Optimal group size can be stable: a reply to Sibly. Anim. Behav, 33 (2), 666-667.

Glowacki, L., Isakov, A., Wrangham, R.W., McDermott, R., Fowler, J.H., Christakis, N.A., 2016. Formation of raiding parties for intergroup violence is mediated by social network structure. Proc. Natl. Acad. Sci., 201610961

Glowacki, L., von Rueden, C., 2015. Leadership solves collective action problems in small-scale societies. Phil. Trans. R. Soc. B 370 (1683), 20150010.

Greene, C., Stamps, J., 2001. Habitat selection at low population densities. Ecology 82, 2091-2100.

Hawkes, K., O'Connell, J.F., 1992. On optimal foraging models and subsistence transitions. Curr. Anthropol. 33, 63-66.

Hockett, B., Creger, C., Smith, B., Young, C., Carter, J., Dillingham, E., Crews, R. Pellegrini, E., 2013. Large-scale trapping features from the Great Basin, USA: the significance of leadership and communal gatherings in ancient foraging societies. Quat. Int. 297, 64-78.

Hooper, P.L., Kaplan, H.S., Boone, J.L., 2010. A theory of leadership in human cooperative groups. J. Theor. Biol. 265 (4), 633-646.

Jazwa, C.S., Kennett, D.J., Winterhalder, B., 2013. The ideal free distribution and settlement history at old Ranch Canyon, Santa Rosa Island, California. In: Jazwa, C.S., Perry, J.E. (Eds.), Californias Channel Islands: the Archaeology of Human-environment Interactions. University of Utah Press, pp. 75-96.

Jazwa, C.S., Kennett, D.J., Winterhalder, B., Joslin, T., 2017. Territoriality and the rise of despotic social organization on western Santa Rosa Island, California. Quat. Int.

Johnson, A., 2014. Binford's Environmental and Hunter-gatherer Frames of Reference Variables. http://ajohnson.sites.truman.edu/data-and-program/. (Accessed June 2017).

Kennett, D.J., Kennett, J.P., 2000. Competitive and cooperative responses to climatic instability in coastal southern California. Am. Antiq. 379-395.

Kennett, D.J., Winterhalder, B., Bartruff, J., Erlandson, J.M., 2009. An ecological model for the emergence of institutionalized social hierarchies on California's Northern Channel Islands. In: Shennan, S. (Ed.), Pattern and Process in Cultural Evolution. University of California Press, Berkeley.

Kramer, D.L., 1985. Are colonies supraoptimal groups? Anim. Behav. 33 (3), 1031-1032.

Krause, J., Ruxton, G.D., 2002. Living in Groups. Oxford University Press.

Kroeber, A.L., 1925. Handbook of the Indians of California. Smithsonian Institution, Bureau of American Ethnology.

Kroeber, A.L., 1955. Nature of the land-holding group. Ethnohistory 2 (4), 303-314.

Lambert, P.M., 1997. Patterns of violence in prehistoric hunter-gatherer societies of coastal southern California. Troubled Times: Violence Warf. Past 77-109.

Lambert, P.M., 2002. The archaeology of war: a North American perspective, J. Archaeol. Res. 207-241.

Lewis, H.T., Ferguson, T.A., 1988. Yards, corridors, and mosaics: how to burn a boreal forest. Hum. Ecol. 16, 57-77.

Lewis, M.P., Simons, G.F., Fennig, C.D., et al., 2009. Ethnologue: Languages of the World, vol. 16. SIL International Dallas, TX.

Magargal, K.E., Parker, A.K., Vernon, K.B., Rath, W., Codding, B.F., 2017. The ecology of population dispersal: modeling alternative basin-plateau foraging strategies 
to explain the Numic expansion. Am. J. Hum. Biol. 29 (4) e23000 1-14.

Marwick, B., Johnson, A., White, D., Eff, E.A., 2016. Binford: Binford's HunterGatherer Data. R package version 0.1.0. . (Accessed June 2017).

Mathew, S., Boyd, R., 2011. Punishment sustains large-scale cooperation in prestate warfare. Proc. Natl. Acad. Sci. 108 (28), 11375-11380.

Mattison, S.M., Smith, E.A., Shenk, M.K., Cochrane, E.E., 2016. The evolution of inequality. Evol. Anthropol. 25, 184-199.

McAuliffe, K., Wrangham, R., Glowacki, L., Russell, A.F., 2015. When cooperation begets cooperation: the role of key individuals in galvanizing support. Phil Trans. R. Soc. B 370 (1683), 20150012.

McCarthy, H., 1993. A Political Economy of Western Mono Acorn Production (Ph.D. thesis). University of California at Davis.

McClure, S.B., Jochim, M.A., Barton, C.M., 2006. Human behavioral ecology, domestic animals, and land use during the transition to agriculture in Valencia, eastern Spain. In: Kennett, D.J., Winterhalder, B. (Eds.), Behavioral Ecology and the Transition to Agriculture. Univeristy of California Press, pp. 197-216.

Mohlenhoff, K.A., Codding, B.F., 2017. When does it pay to invest in a patch? the evolution of intentional niche construction. Evol. Anthropol. 26 (5), 218-227.

Morgan, C., 2012. Modeling modes of hunter-gatherer food storage. Am. Antiq. 77, 714-736.

Morgan, C., 2015. Is it intensification yet? current archaeological perspectives on the evolution of hunter-gatherer economies. J. Archaeol. Res. 1-51. https://doi.org/ 10.1007/s10814-014-9079-3.

Moritz, M., Hamilton, I.M., Chen, Y.-J., Scholte, P., 2014. Mobile pastoralists in the Logone floodplain distribute themselves in an ideal free distribution. Curr. Anthropol. 55 (1), 115-122.

Moritz, M., Hamilton, I.M., Yoak, A.J., Scholte, P., Cronley, J., Maddock, P., Pi, H., 2015. Simple movement rules result in ideal free distribution of mobile pastoralists. Ecol. Model. 305, 54-63.

Moritz, M., Scholte, P., Hamilton, I.M., Kari, S., 2013. Open access, open systems: pastoral management of common-pool resources in the Chad Basin. Hum. Ecol. 41, 351-365.

Moss, M.L., Erlandson, J.M., 1992. Forts, refuge rocks, and defensive sites: the antiquity of warfare along the northpacific coast of North America. Arct. Archaeol. 29, 73-90.

Nettle, D., 2009. Ecological influences on human behavioural diversity: a review of recent findings. Trends Ecol. Evol. 24 (11), 618-624.

O'Connell, J.F., Allen, J., 2012. The restaurant at the end of the universe: modelling the colonisation of Sahul. Aust. Archaeol. 74, 5-17.

Ostrom, E., 1990. Governing the Commons: the Evolution of Institutions for Collective Action. Cambridge University Press.

Parker, A.K., Parker, C.H., Codding, B.F., 2017. When to defend? optimal territoriality across the Numic homeland. Quat. Int

Powers, S.T., Lehmann, L., 2017. When is bigger better? the effects of group size on the evolution of helping behaviours. Biol. Rev. 92, 902-920.

Prufer, K.M., Thompson, A.E., Meredith, C.R., Culleton, B.J., Jordan, J.M., Ebert, C.E., Winterhalder, B., Kennett, D.J., 2017. The Classic Period Maya transition from an ideal free to an ideal despotic settlement system at the polity of Uxbenk. J. Anthropol. Archaeol. 45, 53-68.

R Core Team, 2016. R: a Language and Environment for Statistical Computing. R Foundation for Statistical Computing, Vienna, Austria v.3.3.2 (2016-10-31, Sincere Pumpkin Patch). http://www.R-project.org.

Schwitalla, A.W., Jones, T.L., Pilloud, M.A., Codding, B.F., Wiberg, R.S., 2014. Violence among foragers: the bioarchaeological record from central California. J. Anthropol. Archaeol. 33, 66-83.

Sibly, R.M., 1983. Optimal group size is unstable. Anim. Behav. 31 (3), 947-948.

Smith, E.A., 1985. Inuit foraging groups: some simple models incorporating conflicts of interest, relatedness, and central-place sharing. Ethol. Sociobiol. 6 (1), 27-47.

Smith, E.A., 1988. Risk and uncertainty in the original affluent society: evolutionary ecology of resource-sharing and land tenure. In: Ingold, T., Riches, D. Woodburn, J. (Eds.), Hunters and Gatherers: History, Evolution, and Social Change, vol. 1. Berg, Oxford, pp. 222-251.

Smith, E.A., 1991. Inujjuamiut Foraging Strategies: Evolutionary Ecology of an Arctic Hunting Economy. Aldine de Gruyter, New York.

Smith, E.A., Bliege Bird, R., 2005. Costly signaling and cooperative behavior. In: Gintis, H. (Ed.), Moral Sentiments and Material Interests: the Foundations of Cooperation in Economic Life. MIT Press, Cambridge, MA, pp. 115-148.

Stephens, P.A., Sutherland, W.J., 1999. Consequences of the Allee effect for behaviour, ecology and conservation. Trends Ecol. Evol. 14 (10), 401-405.

Stephens, P.A., Sutherland, W.J., Freckleton, R.P., 1999. What is the Allee effect? Oikos 87, 185-190.

Stevens, N.E., Whitaker, A.R., Rosenthal, J., 2017. Bedrock mortars as indicators of territorial behavior in the Sierra Nevada. Quat. Int.

Steward, J.H., 1938. Basin-plateau Aboriginal Sociopolitical Groups. Bureau of American Ethnology, Washington DC bulletin 120.

Summers, K., 2005. The evolutionary ecology of despotism. Evol. Hum. Behav. 26 (1), 106-135.

Sutherland, W.J., 1996. From Individual Behaviour to Population Ecology. Oxford University Press, Oxford.

Tushingham, S., Bettinger, R.L., 2013. Why foragers choose acorns before salmon: storage, mobility, and risk in aboriginal California. J. Anthropol. Archaeol. 32 $527-537$.

Tushingham, S., Bettinger, R.L., 2017. Expansive and intensive territorialism in hunter-gatherer storage economies. Quat. Int.

Tylor, E.B., 1889. On a method of investigating the development of institutions applied to laws of marriage and descent. J. Anthropol. Inst. G. B. Irel. 18, $245-272$.

Vehrencamp, S.L., 1983. A model for the evolution of despotic versus egalitarian societies. Anim. Behav. 31 (3), 667-682.

Walker, P.L., 1989. Cranial injuries as evidence of violence in prehistoric southern California. Am. J. Phys. Anthropol. 80, 313-323.

Willems, E.P., Arseneau, T.J.M., Schleuning, X., van Schaik, C.P., 2015. Communa range defence in primates as a public goods dilemma. Phil. Trans. R. Soc. B 370 (1683), 20150003.

Williams, G.C., 1966. Adaptation and Natural Selection: a Critique of Some Current Evolutionary Thought. Princeton University Press, New Jersey.

Winterhalder, B., Kennett, D.J., Grote, M.N., Bartruff, J., 2010. Ideal free settlement of California's Northern channel Islands. J. Anthropol. Archaeol. 29, 469-490.

Wood, S.N., 2006. Generalized Additive Models: an Introduction with R. Chapman and Hall/CRC Press.

Wood, S.N., 2012. Mixed Gam Computation Vehicle with gcv/aic/reml Smoothness Estimation, V. 1.7-18. http://cran.r-project.org/web/packages/mgcv.

Yaworsky, P.M., Codding, B.F., 2018. Ideal distribution of farmers: explaining the Euro-American settlement of Utah. Am. Antiq. https://doi.org/10.1017/ aaq.2017.46. 